\title{
Physicochemical Properties and Bioactivities of Six Alpinia Species in Sri Lanka
}

\author{
Research Article
}

\section{Bhagya Samarasinghe ${ }^{1}$, Ewon Kaliyadasa ${ }^{1 *}$, Piyal Marasinghe ${ }^{2}$}

\author{
1. Department of Export Agriculture, Uva Wellassa University, Badulla, 90000, Sri Lanka. \\ 2. Uva Provincial Department of Ayurvedha, Diyathalawa, Sri Lanka.
}

\begin{abstract}
Plants comprising bioactive substances with therapeutic value have progressively become the object of research studies. Many species of the genus Alpinia provide a variety of medicinal properties. This study was undertaken to study the biological activities and physicochemical properties of rhizomes and leaves of six Alpinia species available in Sri Lanka namely, Alpinia malaccensis, Alpinia calcarata, Alpinia galanga, Alpinia nigra, Alpinia calcarata Wild and Alpinia purpurata. Physicochemical parameters will be helpful in standardization for quality, purity and authentication of these medicinal plants. Methanol extracts from rhizomes and leaves were screened for total polyphenol content (TPC), antioxidant activity and $\alpha$-amylase inhibition activities. Extracted powders were analysed for physicochemical constants such as loss on drying, total ash, acid -insoluble ash and watersoluble ash contents. The TPC of dried leaves of Alpinia calcarata Wild was the highest of all tested as $2.186 \pm 0.027 \mathrm{~g}$ of GA equivalents per $1 \mathrm{~g}$ of dried rhizome. The Methanol extracts of the rhizome and leaf samples of six species showed reasonable antioxidant activity in the DPPH radical scavenging assay. Interestingly the rhizome extracts of Alpinia nigra and Alpinia purpurata exhibited higher $\alpha$-amylase inhibitory activities $(29.417 \pm 0.507$ and $29.676 \pm$ $0.107 \mu \mathrm{g} / \mathrm{mL}$ respectively) compared with the Acarbose, which is an anti-diabetic drug $(28.273 \pm 0.615 \mu \mathrm{g} / \mathrm{mL})$. The results revealed that the Sri Lankan Alpinia species have a potency to be used as a source of antioxidant and antidiabetic agents and it is important to increase the value of the unexplored medicinal herbs available in Sri Lanka.
\end{abstract}

Key Words: Alpinia, Antioxidant, Antidiabetic, Biological Activities, Physicochemical.

\section{Introduction}

Variations of family Zingiberaceae in the Southeast Asian tropics has been a key factor for the existence of more genera of Zingiberaceae in the Southeast Asia than anywhere else in the world (1). Alpinia has been reported as the dominant genus of the family in this specific region and hence it is the largest genus of the family Zingiberaceae (2). However, the diversity of Zingiberaceae in the Indian sub-continent and Sri Lanka shows a contrasting pattern by having more Amomum species than Alpinia species compared to the other regions (3). Although the genus Alpinia was first classified by Plumier, it was named by Italian botanist Prospero Alpino after the $16^{\text {th }}$ century. This genus belongs to the division Magnoliophyta (Angiospermae), the subclass Zingiberidae and the order Zingiberales (4). It is distinguished morphologically by the presence of rhizome, simple wide leaves, attractive bracts and terminal inflorescence. All parts of the plants in this genus are aromatic in nature due to the presence of numerous components of essential oils. The most outstanding trait

* Corresponding Author:

Ewon Kaliyadasa

Department of Export Agriculture,

Uva Wellassa University,

Badulla, 90000,

Sri Lanka.

Email Id: ewon101k@yahoo.com,ewon@uwu.ac.1k of this genus is the attractiveness of its inflorescence, which explains its wide ornamental use. Furthermore, it bears substantial medicinal uses in many parts of the world. The medicinal properties of this genus are related to different parts of the plant such as leaves, flowers and rhizomes (5).

Alpinia is one of the most widely used medicinal plant in Ayurvedic and traditional medicinal preparations of Sri Lanka. Recently, investigations of the genus Alpinia have been focused on its biological activities. Phytochemical studies have resulted in the isolation of diarylheptanoids, terpenes, and other compounds from the plant (6). Majority of the compounds isolated from this genus show multiple medical potential and usually possess novel chemical structures (7).

Though Alpinia plants have different morphological characters, chemical compounds and medicinal uses, different regions in Sri Lanka have used various plant species under the same common name. For instance, Alpinia calcarata plant is commonly referred as "Heen Araththa". But in different regions many of the Alpinia species including Alpinia calcarata, Alpinia galanga, Alpinia purpurata and Alpinia nigra referred as "Araththa" by the common name for genus "Alpinia".

Therefore, this study was aimed to investigate the physicochemical properties and different bioactivities of six Alpinia species abundant in Sri Lanka namely; Alpinia malaccensis, Alpinia calcarata, Alpinia galanga, Alpinia nigra, Alpinia calcarata Wild 
and Alpinia purpurata. The present study will provide an important comparison of Alpinia plants grown in Sri Lanka by their physicochemical composition as well as in biological activities.

\section{Materials and Methods General}

Chemicals used for the extractions were purchased from Sigma Aldrich, unless otherwise stated. Samples were grinded by high speed universal disintegrator (Model HSD-80). Plant materials were extracted by an Ultrasonic Sonicator (BIOBASE model-UC-10A). Absorbances were measured on a microplate reader (Thermo scientific- Mutiscan Go) using 96 well plate.

\section{Sample Collection and Extraction}

Fresh rhizomes and leaves of six Alpinia species were collected from both intermediate zone and dry zone of Sri Lanka, Alpinia malaccensis (Koslanda, Badulla district- IM2a), Alpinia calcarata (Haldummulla, Badulla district- IM2a), Alpinia galanga (Koslanda, Badulla district- IM2a), Alpinia nigra (Bibile, Monaragala district-IL1c), Alpinia calcarata Wild (Miriswaththe, Badulla District- IM2a) and Alpinia purpurata (Dambulla, Matale district- DL1b). Specimens of each species were authenticated by the National Herbarium, Peradeniya, Sri Lanka. [Voucher Numbers: Alpinia malaccensis-PEKAM-26022020(UWU), Alpinia calcarata- PEKAC-26022020(UWU), Alpinia galanga- PEKAG-26022020(UWU), Alpinia nigra- PEKAN-26022020(UWU), Alpinia calcarata Wild- PEKACW-26022020(UWU), Alpinia purpurata- PEKAP-26022020(UWU)].

Fresh rhizomes $(250 \mathrm{~g})$ were cleaned, cut into small pieces and oven dried at $45{ }^{\circ} \mathrm{C}$ for 12 hours. Leaves were oven dried at $40{ }^{\circ} \mathrm{C}$ for 12 hours. Dried samples were grinded into a fine powder and stored in sealed containers for physicochemical analysis. $10 \mathrm{~g}$ of fine powder was extracted with $\mathrm{MeOH}$. $\mathrm{MeOH}$ was evaporated by rotary evaporator model HS-2005V with $40{ }^{\circ} \mathrm{C}$ of inner bulb temperature to obtain the plant extract. $\mathrm{MeOH}$ extracts from rhizomes and leaves were screened for total polyphenol content, antioxidant activity and $\alpha$-amylase inhibition activities.

\section{Analysis of Physicochemical Properties}

Physicochemical properties were analysed according to the methods used by Liyanage et al. (2012) (8).

\section{Determination of Loss on Drying}

Cleaned empty crucibles were taken and their weights were measured using analytical balance and labelled accordingly. Then $1 \mathrm{~g}$ of rhizome and leaf powder was weighed into crucibles and closed with lid to keep in a preheated oven for 1 hour at $105^{\circ} \mathrm{C}$. After that crucibles were taken out and kept in a desiccator for cooling. There after samples were weighed using the analytical balance. Three replicates were used to take readings. Loss in weight was recorded as a percentage of dry weight.

\section{Determination of Total Ash Value}

Crucibles were kept with the lid in the furnace at $550^{\circ} \mathrm{C}$ overnight so as to ensure whether the impurities on the surface of crucible are burned off. Crucibles are then cooled in the desiccator for 30 minutes and were weighed to 3 decimal places with their lids. $2 \mathrm{~g}$ of powdered samples were weighed into the crucible and heated over low Bunsen flame with lid half covered. Immediately after when fumes are no longer produced, crucibles and lids are placed in the furnace and kept at $550^{\circ} \mathrm{C}$ for $3 \mathrm{hrs}$. During heating the lid are kept open. The lids are placed after complete heating to prevent loss of fluffy ash. Thereafter all the items were kept in the desiccator for 30 minutes to cool down. The ash with crucible and lid were weighted when the samples turns to grey. If not, the crucibles and lid are returned to the furnace for the further ashing. Then the percentage of the total ash with reference to dried powdered samples were calculated.

\section{Acid - Insoluble Ash}

Ash was taken and dissolved in $25 \mathrm{~mL}$ of $2 \mathrm{~N}$ $\mathrm{HCl}$. It was boiled for 5 min over a Bunsen burner and filtered through filter paper (Whatmann No: 42). Filtrate was washed with hot water until the filtrate is free from acid. It was checked using blue litmus. When the filtrate is free from acid the filter paper is transferred into crucibles and incinerate. The crucibles were put into the muffle furnace at $550^{\circ} \mathrm{C}$ for 3 hours and re-ashed. After that crucibles were transferred to the desiccator. When it is cooled the sample was weighed and calculated the acid insoluble ash percentage with reference to the dried powder samples.

\section{Water - Soluble Ash}

The ash was washed from the crucible into an empty beaker using $25 \mathrm{~mL}$ of chloroform water and it was boiled for $5 \mathrm{~min}$ over a Bunsen burner and filtered through ash less filter paper (Whatmann No: 42). The residue was washed with hot water twice, ignited to ash cooled and weighed. The weight of insoluble matter was subtracted from the weight of ash. The difference in weight represents the water-soluble ash. The percentage of water - soluble ash was calculated with reference to dried powder.

\section{Analysis of Biological Activities Total Polyphenol Content (TPC)}

TPC was determined by the Folin-Ciocalteu reagent method (9). Gallic acid (GA) series from 5-500 $\mu \mathrm{g} / \mathrm{mL}$ was used to prepare a standard curve. A $100 \mu \mathrm{L}$ of each GA solution was mixed with $100 \mu \mathrm{L}$ of distilled water and $500 \mu \mathrm{L}$ of 10 times diluted Folin-Ciocalteu reagent. After $5 \mathrm{~min}, 800 \mu \mathrm{L}$ of $7.5 \%$ (w/v) $\mathrm{Na}_{2} \mathrm{CO}_{3}$ solution was added to the mixture and allowed to stand at room temperature for $60 \mathrm{~min}$. Absorbance at $765 \mathrm{~nm}$ was measured against distilled water. A $100 \mu \mathrm{L}$ of a test solution was prepared from $\mathrm{MeOH}$ extract of dried rhizomes and leaves separately. They were also treated 
as described above. The phenolic content (mass of polyphenols) was read from the standard curve as GA equivalents (GAE) per 1g of rhizome/ leaves.

\section{Antioxidant Activity}

The crude extracts of rhizomes and leaves $(100-1000 \mu \mathrm{g} / \mathrm{ml})$ were tested using the1,1-diphenyl-2picrylhydrazyl (DPPH) assay (10). $0.75 \mathrm{~mL}$ of each solution was mixed with $0.3 \mathrm{~mL}$ of a $0.3 \mathrm{mM} \mathrm{DPPH}$ $\mathrm{MeOH}$ solution and kept in the dark at room temperature for $30 \mathrm{~min}$. The absorbance was measured at $518 \mathrm{~nm}$ against a reaction blank $(0.3 \mathrm{~mL}$ of $\mathrm{MeOH}$ and $0.75 \mathrm{~mL}$ of the plant extract). A mixture of $0.3 \mathrm{~mL}$ of $0.3 \mathrm{mM}$ DPPH solution and $0.75 \mathrm{~mL}$ of $\mathrm{MeOH}$ was used as a reaction control against $\mathrm{MeOH}$. Percent inhibition was calculated for each concentration and $\mathrm{IC}_{50}$ was calculated for each extract. Ascorbic acid was used as positive controls $(0.1-5 \mu \mathrm{g} / \mathrm{ml})$. The following formula was used to calculate the percentage inhibition.

$$
\text { Percentage inhibition }=\frac{A b s_{\text {negative control }}-A b s_{\text {sample }}}{A_{\text {negative control }}} \times 100
$$

Concentration at $50 \%$ inhibition was calculated by plotting dose response curves of percentage inhibition vs. concentration as $\mathrm{IC}_{50}$ values.

\section{a-Amylase Inhibition Assay}

The dinitrosalicylic acid (DNSA) color reagent method was used (11). DNSA was prepared using 96 $\mathrm{mM}$ 3,5-dinitrosalicylic acid in $20 \mathrm{~mL}$ of deionized water, $5.31 \mathrm{M}$ sodium potassium tartrate in $8 \mathrm{~mL}$ of $2 \mathrm{M}$ $\mathrm{NaOH}$ and $12 \mathrm{~mL}$ of deionized water. $\alpha$-Amylase (Type 1-A, porcine pancreas, $20 \mathrm{mg}$ protein/mL: $1184 \mathrm{U} / \mathrm{mg}$ ) was dissolved in $20 \mathrm{mM}$ phosphate buffer $(\mathrm{pH} 6.9$, containing $6.7 \mathrm{mM} \mathrm{NaCl}$ ). Plant extracts were dissolved in deionized water with $1 \%$ dimethyl sulfoxide (DMSO) (5-500 ppm extracts). A $100 \mu \mathrm{L}$ of $\alpha$-amylase ( $8 \mathrm{U} / \mathrm{mL}$ ) was mixed with $100 \mu \mathrm{L}$ of plant extract and incubated at $25{ }^{\circ} \mathrm{C}$ for $30 \mathrm{~min}$. A $100 \mu \mathrm{L}$ of this mixture was mixed with starch $(0.5 \% \mathrm{w} / \mathrm{v})$ solution $(100 \mu \mathrm{L})$, incubated at $37^{\circ} \mathrm{C}$ for $10 \mathrm{~min}$, DNSA reagent $(100 \mu \mathrm{L})$ was added, incubated at $85^{\circ} \mathrm{C}$ in a water bath for $15 \mathrm{~min}$, allowed to cool and then diluted with distilled water $(900 \mu \mathrm{L})$. Negative controls were conducted in the same manner replacing plant extracts with $1 \%$ DMSO $(100 \mu \mathrm{L})$ in deionized water. Blanks were prepared by adding DNSA reagent prior to the addition of starch solution to denature the enzyme, kept in $85{ }^{\circ} \mathrm{C}$ water bath for 15 min and then diluted with distilled water $(900 \mu \mathrm{L})$ as before. Absorbance was measured at $540 \mathrm{~nm}$ and percent inhibition was plotted against concentration to calculate $\mathrm{IC}_{50}$. Acarbose $(1-250 \mathrm{ppm})$ was used as the positive control.

\section{Statistical analysis}

All the experiments in this study were done in triplicate and the results were expressed as means along with Standard Deviation (SD). SD were calculated by Microsoft Excel 2019. Data were analysed by analysis of variance (ANOVA). Means were separated by Tukey pairwise comparison $(\mathrm{p}<0.05)$ with Minitab 17 software.

\section{Results and Discussion}

The results of the physicochemical studies are tabulated in Table 1 and 2. The quality control parameters for the raw materials were recognized with the help of several official determinations based on physicochemical parameters. Results revealed that the total ash contents of all selected Alpinia rhizomes were higher than the total ash content of leaves. The results obtained in the present study for the ash values were almost similar with that of Liyanage et al. (2012) (8). But the ash values obtained by Ajay and Vijaykumar, (2015) is higher than the values of present study (Table 01) (12).

Controlled incineration of crude drugs results in an ash residue consisting of inorganic materials such as metallic salts and silica. This value varies within independently wide limits and it is therefore an important parameter for the purpose of evaluation of crude drugs. More direct contamination, such as by sand or earth, is immediately detected by the ash value and the results were observed slightly higher due to contamination or unwanted parts of the drug (13).

Physicochemical screening of Alpinia galanga reported different values for the rhizome and leaves by Swati Shukla et al. (2018) were almost similar with the results obtained in the present study for the ash values (14). They have concluded that these values can be used as a diagnostic tool for the correct identification of the leaves, stem, root and rhizomes of Alpinia galanga drugs.

The physicochemical analysis of rhizome and volatile oil of Alpinia speciosa rhizome were investigated and reported (15). There, the total ash value was found to be $3.98 \% \mathrm{w} / \mathrm{w}$ indicating the considerable presence of inorganic materials. The acid insoluble ash, water soluble ash was found to be $0.40 \% \mathrm{w} / \mathrm{w}$ and $2.80 \% \mathrm{w} / \mathrm{w}$ respectively. However, the ash values reported from the present study shows slight variations with these values (Table 01).

The general requirement for the moisture content in crude drugs is less than $14 \%$. The additional moisture can result in the breakdown of important ingredients by enzymatic activity and which may increase the growth of yeast and fungi during storage (16). According to Jayanthy et al. (2013), the value of moisture content was high in the plants collected in the rainy season and the seasonal variation is associated with the vegetative and reproductive stages of the plant, it has direct influence with the variation in chemical constituents of the plants also (17). 
Bhagya Samarasinghe et.al., Physicochemical Properties and Bioactivities of Six Alpinia Species in Sri Lanka

Table 1 - Physicochemical Parameters of Rhizomes in Different Alpinia Species

\section{Physicochemical Constant}

Alpinia malaccensis

Alpinia calcarata

Alpinia galanga

Alpinia nigra

Alpinia calcarata wild

Alpinia purpurata

\section{Loss On Drying}

$(\mathbf{W} / \mathbf{W}) \%$

$19.14^{d} \pm 0.06$
$22.01^{c} \pm 0.02$
$24.99^{b} \pm 0.02$
$15.03^{e} \pm 0.15$
$25.09^{b} \pm 0.18$
$30.12^{a} \pm 0.12$

Total Ash Value

(W/W)\%
Acid Insoluble

Ash Value

$(\mathrm{W} / \mathrm{W}) \%$

$0.53^{\mathrm{a}} \pm 0.01$

$0.48^{b} \pm 0.01$

$0.42^{c} \pm 0.01$

$0.38^{\mathrm{d}} \pm 0.01$

$0.47^{b} \pm 0.01$

$0.39 \mathrm{~d} \pm 0.01$
Water Soluble

Ash Value

(W/W)\%

$15.28^{\mathrm{b}} \pm 0.02$

$14.57 \mathrm{~d} \pm 0.01$

$15.64^{\mathrm{a}} \pm 0.01$

$12.34 \mathrm{f} \pm 0.03$

$14.66^{\mathrm{c}} \pm 0.02$

$13.59 \mathrm{e} \pm 0.01$

Means within the same column followed by different letters are significantly different at $\mathrm{p}<0.05$

Table 2 - Physicochemical Parameters of Leaves in Different Alpinia Species

\section{Physicochemical Constant}

\begin{abstract}
Alpinia malaccensis
Alpinia calcarata

Alpinia galanga

Alpinia nigra

Alpinia calcarata wild

Alpinia purpurata
\end{abstract}

Loss On Drying
$(\mathrm{W} / \mathrm{W}) \%$

$20.04 \mathrm{c} \pm 0.07$

$19.76^{c} \pm 0.06$

$23.19^{\mathrm{b}} \pm 0.32$

$14.91 \mathrm{e} \pm 0.38$

$16.12^{\mathrm{d}} \pm 0.13$

28. $07^{\mathrm{a}} \pm 0.14$

\section{Total Ash Value (W/W)\%}

Acid Insoluble Ash Value

(W/W)\%

$0.98^{\mathrm{a}} \pm 0.01$

$0.77 \mathrm{c} \pm 0.01$

$0.87 \mathrm{~b} \pm 0.01$

$0.88^{b} \pm 0.02$

$0.75^{\mathrm{c}} \pm 0.01$

$0.82^{\mathrm{bc}} \pm 0.07$
Water Soluble

Ash Value

(W/W)\%

$12.70^{\mathrm{a}} \pm 0.05$

$11.58^{\mathrm{c}} \pm 0.30$

$11.81^{\mathrm{b}} \pm 0.01$

$10.31^{\mathrm{e}} \pm 0.02$

$11.53^{\mathrm{c}} \pm 0.01$

$10.97 \mathrm{~d} \pm 0.01$

Means within the same column followed by different letters are significantly different at $\mathrm{p}<0.05$

The present study revealed that Alpinia species contain more moisture content and that indicates more chances of microbial degradation of the drug during storage and more suitable to medicinal preparations. But these values may be changing due to the seasonal variations and other different factors.

The orange to reddish brown $\mathrm{MeOH}$ rhizome extracts and greenish $\mathrm{MeOH}$ leaf extracts from the Alpinia species noted positive results for antioxidant activity and $\alpha$-amylase activity. Further all samples were rich in phenolics. The total polyphenol contents (TPC) of six Alpinia species are indicated in Table 3.

\section{Species}

Alpinia malaccensis

Alpinia calcarata

Alpinia galanga

Alpinia nigra

Alpinia calcarata wild

Alpinia purpurata

Table 3 - Total Polyphenol Content of Six Alpinia Species

Means within the same column followed by different letters are significantly different at $\mathrm{p}<0.05$

\section{Rhizome}

$1.616^{\mathrm{a}} \pm 0.006$

$0.848^{\mathrm{b}} \pm 0.016$

$0.610^{c} \pm 0.004$

$0.311 \mathrm{e} \pm 0.003$

$0.791^{\mathrm{b}} \pm 0.049$

$0.462 \mathrm{~d} \pm 0.029$

Total Polyphenol Content ( $\mathrm{g}$ of GA equivalents/ $1 \mathrm{~g}$ dried powder)

Leaf

$2.034^{\mathrm{b}} \pm 0.004$

$2.010^{\mathrm{b}} \pm 0.004$

$1.991^{\mathrm{c}} \pm 0.005$

$2.039 \mathrm{~b} \pm 0.009$

$2.186^{\mathrm{a}} \pm 0.027$

$2.040^{\mathrm{b}} \pm 0.008$

The TPC of dried leaves of Alpinia calcarata wild was found to be the highest among all and recorded as $2.186 \pm 0.027 \mathrm{~g}$ of GA equivalents $/ 1 \mathrm{~g}$ dried leaves. Further leaves of Alpinia nigra, Alpinia purpurata and Alpinia malaccensis were recorded high polyphenol contents compared to rhizomes.

According to the researchers' point of view Alpinia galanga is gaining big interest due to its biological activity (5). 1'S-1'-acetoxychavicol acetate is the major compound so far reported with various biological activities isolated from Alpinia galanga (18).

The polyphenol contents are closely related with their medicinal uses since phenolic compound can act as anti-oxidant by free radical scavengings/ antioxidant property (19). The present findings show the polyphenol contents of Sri Lankan Alpinia Species are relatively high. That makes Alpinia species a suitable plant with economic importance having medicinal values, hence may be utilized as raw materials for pharmaceutical industries. Interestingly leaves of all six Alpinia species has significantly higher TPC compared to the rhizomes hence can be used as a source of raw material easily.

The $\mathrm{MeOH}$ extracts of Alpinia species showed outstanding radical scavenging activity against the free radicals (Table 4). Enhanced antioxidant property was observed in the extract of Alpinia purpurata rhizome (IC50 $237.303 \pm 0.556 \mathrm{ppm})$ and well suited with the similar antioxidant activities of some Alpinia species reported by Heo et al. (2001) (20). However, the considerable antioxidant activity of the Alpinia species in present study could be a result of biologically active compounds in Alpinia such as 1'S-1'-acetoxychavicol acetate. However, a big potential is available to utilize both leaves and rhizomes of Sri Lankan Alpinia species as a source of antioxidants. 
Table 4 - IC I0 $_{50}$ Values of DPPH Radical Scavenging Activity

\section{Species}

\begin{tabular}{l|c} 
& Rhizome \\
\hline Alpinia malaccensis & $381.871^{\mathrm{b}} \pm 0.735$ \\
\hline Alpinia calcarata & $336.643^{\mathrm{c}} \pm 0.414$ \\
\hline Alpinia galanga & $261.857^{\mathrm{e}} \pm 0.483$ \\
\hline Alpinia nigra & $399.040^{\mathrm{a}} \pm 0.703$ \\
\hline Alpinia calcarata wild & $328.578^{\mathrm{d}} \pm 0.517$ \\
\hline Alpinia purpurata & $237.303^{\mathrm{f}} \pm 0.556$ \\
\hline Ascorbic acid (Standard) & $0.5655^{\mathrm{g}} \pm 0.056$
\end{tabular}

\section{IC $_{50}$ Values of DPPH radical scavenging activity $(\mu \mathrm{g} / \mathrm{mL})$}

Leaf

$434.701^{c} \pm 0.939$

$411.866^{\mathrm{d}} \pm 0.442$

$316.557^{\mathrm{f}} \pm 0.601$

$474.189^{\mathrm{a}} \pm 0.336$

$410.277 \mathrm{e} \pm 0.249$

$459.835^{\mathrm{b}} \pm 0.238$

$0.565^{\mathrm{g}} \pm 0.056$

Means within the same column followed by different letters are significantly different at $\mathrm{p}<0.05$

The $\mathrm{MeOH}$ extracts of Alpinia species exhibited high level of inhibition to $\alpha$-amylase enzyme under in vitro conditions (Table 5). Inhibitory concentrations of crude extracts that required $50 \%$ inhibition against $\alpha$-amylase in Alpinia nigra $(29.417 \mu \mathrm{g} / \mathrm{mL})$ and Alpinia purpurata $(29.676 \mu \mathrm{g} / \mathrm{mL})$ rhizomes were almost similar compared to Acarbose a clinical drug that act as the inhibitor of $\alpha$-amylase $(28.273 \mu \mathrm{g} / \mathrm{mL})$ determined under identical conditions. However, confirmation of antioxidant and antidiabetic activity of these species under in vivo conditions and in an animal models are essential to use as medicines.

Table 5 - IC 50 Values of $\alpha$-amylase Inhibition Activity

Species

Alpinia malaccensis

Alpinia calcarata

Alpinia galanga

Alpinia nigra

Alpinia calcarata wild

Alpinia purpurata

Acarbose (Standard)
$\mathrm{IC}_{50}$ Values of $\alpha$-amylase Inhibition Activity $(\mu \mathrm{g} / \mathrm{mL})$ Rhizome

$160.146^{\mathrm{a}} \pm 0.167$

$153.582^{b} \pm 0.372$

$54.312^{\mathrm{d}} \pm 0.255$

$29.417 \mathrm{e} \pm 0.507$

$102.011^{\mathrm{c}} \pm 0.012$

$29.676^{\mathrm{e}} \pm 0.107$

$28.273^{\mathrm{f}} \pm 0.615$
Leaf

$90.963^{b} \pm 0.127$

$100.323^{\mathrm{a}} \pm 0.517$

$72.319^{\mathrm{c}} \pm 0.251$

$50.149 \mathrm{e} \pm 0.134$

$65.447 \mathrm{~d} \pm 0.384$

$48.624 \mathrm{f} \pm 0.177$

$28.273 \mathrm{~g} \pm 0.615$

Means within the same column followed by different letters are significantly different at $\mathrm{p}<0.05$

According to the studies of Nivetha et al. (2019) in vitro $\alpha$ amylase inhibitory activities of the methanolic extract of root of Alpinia purpurata showed that, there was a dose-dependent increase in percentage inhibitory activity against $\alpha$ amylase enzyme from $39.80 \pm 0.62$ to $66.10 \pm 0.38 \%$ (21). The present study shows higher $\alpha$ amylase inhibition capacity in Sri Lankan Alpinia purpurata than Indian Alpinia Species.

Sudipta and Latha, (2014) have explored the efficacy of Alpinia nigra seed extract towards the inhibition of the key regulatory enzyme, $\alpha$ amylase, involved in diabetes (22). Their findings unveil Alpinia nigra seeds as a rich source of antidiabetic compounds for its future therapeutic application as an alternative herbal means. According to our findings, Sri Lankan Alpinia nigra rhizome also can be used as a rich source of antidiabetic agents.

\section{Conclusion}

Although the Alpinia genus is known for its diverse biopharmaceutical potential, reports associated with the antidiabetic property are inadequate. The genus Alpinia represents many species, some of them are fully explored but many species are not much studied. The present study shows that Sri Lankan Alpinia species have a great potential to be used as antioxidant and antidiabetic agents. In the present study rhizomes and leaf samples of six Alpinia species were thoroughly investigated for their physicochemical characters to analyse their quality, safety and standardization to compare with different standards. The information from the present study will provide a track to compare bioactivity of different Alpinia species with correct identification and authentication of these herbal materials to be utilized in herbal industry by preventing its adulteration.

\section{Acknowledgment}

The financial support given by the University Research Grants of Uva Wellassa University under the grant number of UWU/RG/2018/016 is highly acknowledged.

\section{References}

1. Kress W.J, Price L.M, Williams K.J, The phylogeny and new classification of the gingers (ingiberaceae): Evidence from molecular data. Am. J. Bot. 2002; 89; 1682-1696.

2. Larsen K, Friis I, Balslev H, Distribution patterns and diversity centres of Zingiberaceae in SE Asia. Biol. Skr. 2005; 55; 219-228.

3. Droop A.J. Systematic and biogeographic studies in the genus Amomum Roxb. (Zingiberaceace) in sumatra. University of Aberdeen; 2012.

4. Kress W.J, Liu A.Z, Newman M, Li Q.J, The molecular phylogeny of Alpinia (Zingiberaceae): a complex and polyphyletic genus of gingers. Am. J. Bot. 2005; 92; 167-178. https://doi.org/ 10.3732/ ajb.92.1.167. 
Bhagya Samarasinghe et.al., Physicochemical Properties and Bioactivities of Six Alpinia Species in Sri Lanka

5. Anirban C, Santanu P, A Review on Phytochemical and Pharmacological Potential of Alpinia galangal. Pharmacogn. J. 2018; 10; 9-15. https://doi.org/ 10.5530/pj.2018.1.2.

6. Zhang W.J, Jian-Guang Luo, Ling-Yi Kong, The Genus Alpinia: A Review of Its Phytochemistry and Pharmacology. World J. Tradit. Chin. Med. 2015; 2(1);26-41. https://doi.org/10.15806/ j.issn.2311-8571.2015.0026.

7. Xiao-Ni Ma, Chun-Lan Xie, Zi Miao, Quan Yangb, Xian-Wen Yang, An overview of chemical constituents from Alpinia species in the last six decades. RSC Adv. 2017; 7; 14114-14144. https:// doi.org/10.1039/C6RA27830B.

8. Liyanage D.A, Arawwawala M, Lakshmi S, Arambewela R, Wanigasekara D, Ratnasooriya, Alpinia calcarata Roscoe: A Rich Source of Phytopharmaceuticals in Sri Lanka. The Nat. Pro. J. $2012 ; 2$ ( 4 ); 4. h t tps :// doi .org/ 10.2174/2210315511202040263.

9. Khan T, Ahmad M, Khan H, Ahmad W, Standardization of Crude Extracts Derived from Selected Medicinal Plants of Pakistan for Elemental Composition Using SEM-EDX. Asian J. Plant Sci. 2006; 5; 211-216. https://doi.org/ 10.3923/ ajps.2006.211.216.

10. Silva C.G, Herdeiro R.S, Mathias C.J, Panek A.D, Silveira C.S, Rodrigues V.P, Renno M.N, Falcão D.Q, Cerqueira D.M, Minto A.B.M, Noguera F.L.P, Quaresma C.H, Silva J.F.M, Menezes F.S, Eleutherio E.C.A, Evaluation of antioxidant activity of Brazilian plants. Pharmacol. Res. 2005; 52; 229233. https://doi.org/ 10.1016/j.phrs.2005.03.008.

11. Nickavar B, Abolhasani L, Izadpanah $H, \alpha$-amylase inhibitory activities of six Salvia species. Iran. J. Pharm. Res. 2008; 7; 297-303.

12. Ajay G.N, Vijaykumar M.K, Comparative Pharmacognostic and phytochemical investigation of two Alpinia species from zingiberaceae family. World J. Pharm. Res. 2015; 4(5); 1417-1432.

13. Hua S.Z, Luo J.G, Wang X.B, Wang J.S, Kong L.Y, Two novel monoterpene-chalcone conjugates isolated from the seeds of Alpinia katsumadai. Bioorg. Med. Chem. Lett. 2009; 19; 2728-2730. https://doi.org/ 10.1016/j.bmcl.2009.03.117.

14. Swati Shukla, Sanjeev Kumar Ojha, Gaurav K Mishra, Sheelu Gupta, T Venu Gopal Roy, A review of comparative pharmacognostic and phytochemical study of drugs mentioned as Rasna: (Pluchea lanceolata (DC.) Oliv. \& Hiern verses Alpinia galanga (L.) Willd.) J. Pharm. Phytochem. 2018; 7(3); 2410-2416.

15. Thenmozhi S, Sumeet Dwivedi, Mohit Chaturvedi, Abhishek Dwivedi, Subasini U, Pharmacognostical, Physicochemical and Chromatographic estimation of rhizomes and rhizome oil of Alpinia speciosa Roxb. Int. J. Drug discovery and herbal Res. 2013; 3(3); 649-651.

16. Essiett U.A, Edet N.I, Bala D.N, Phytochemical and physicochemical analysis of the leaves of Laportea aestuans (Linn.) Chew and Laportea ovalifolia (Schumach.) Chew (male and female). Asian J. Plant Sci. Res. 2011; 1(2); 35-42.

17. Jayanthy A, Prakash K.U, Remashree A.B, Seasonal and Geographical Variations in Cellular Characters and Chemical Contents in Desmodium gangeticum (L.) DC. - An Ayurvedic Medicinal Plant. Int. J. Herbal Med. 2013; 2(3); 34-37.

18. Baradwaj R.G, Rao M.V, Senthil K.T, Novel purification of 1'S-1'-Acetoxychavicol acetate from Alpinia galanga and its cytotoxic plus antiproliferative activity in colorectal adenocarcinoma cell line SW480. Biomed. Pharmacother. 2017; 91; 485. https://doi.org/ 10.1016/j.biopha.2017.04.114.

19. Kosem N, Han Y.H, Moongkarndi P, Antioxidant and cytoprotective activities of methanolic extract from Garcinia mongostana Hulls. Sci Asia. 2007; 33; 283-292. https://doi.org/ 10.2306/ scienceasia1513-1874.2007.33.283.

20. Heo M.Y, Sohn S.J, Au W.W, Anti-genotoxicity of galangin as a cancer chemopreventive agent candidate. Mutation Res. 2001; 488(2); 135-150. https://doi.org/ 10.1016/s1383-5742(01)00054-0.

21. Nivetha V, Subramaniyan V, Manikandan G, Divya Bharathi M, Krishna Prasanth T, Manjula K, In vitro antidiabetic and antioxidant activities of the methanolic extract of Alpinia purpurata root, J. Pharm. Phytochem. 2019; 8(3); 1060-1064.

22. Sudipta G, Latha R, Molecular docking and inhibition studies of a-amylase activity by labdane diterpenes from Alpinia nigra seeds. Med. Chem. Res. 2014; 1-18. https://doi.org/10.1007/ s00044-014-1056-3. 